\title{
The Influence of Highly Dispersed Metal Forms on Calcium and Phosphorus Metabolism in Polygastric Animals
}

\author{
Makaeva Ayna Maratovna ${ }^{1}$, Sizova Elena Anatolevna ${ }^{1,2}$, and Atlanderova \\ Ksenya Nikolaevna ${ }^{1}$ \\ ${ }^{1}$ Federal Research Centre of Biological Systems and Agrotechnologies of the Russian Academy \\ of Sciences (Orenburg, Russia), 299 Yanvarya St., 460000 \\ ${ }^{2}$ Orenburg State University (Orenburg, Russia) \\ ORCID
}

Makaeva Ayna Maratovna; 0000-0003-1474-8223

Corresponding Author: Makaeva

Ayna Maratovna; email:

ayna.makaeva@mail.ru

\section{Dates}

Published 13 January 2022

Publishing services provided by Knowledge E

(c) Makaeva Ayna Maratovna et al. This article is distributed under the terms of the Commons Attribution License, which permits unrestricted use and redistribution provided that the original author and source are credited.

Selection and Peer-review under the responsibility of the 8th Scientific and Practical Conference Conference Committee.
Abstract. Determining which forms of mineral feed additives can increase farm animal productivity is a key area of research. This study assessed the mineral composition of ruminal fluid and the effectiveness of calcium and phosphorus used by animals after the introduction of finely dispersed particles (FDP) of $\mathrm{SiO}_{2}$ (group I) and FeCo (group II) with a hydrodynamic radius of $109.6 \pm 16.6$ and $265 \pm 25 \mathrm{~nm}$, respectively. The deposition and use of calcium and phosphorus in the body of the experimental animals exceeded the control values. In group I, 30.8\% more calcium was deposited ( $p$ $\geq 0.05$ ), and in group II, the value was $30.3 \%$ ( $p \geq 0.01$ ). In the experimental groups, the calcium utilization rate was $27.3 \%$ higher in group I ( $p \geq 0.05$ ), and $28.2 \%$ higher in group II ( $p \geq 0.01$ ) compared to in the control. Phosphorus deposition was $34 \%$ higher ( $p \leq 0.01$ ) in experimental group I and $6 \%$ higher in experimental group II, compared with the control. Group I had a high utilization rate of phosphorus from the feed (with a $29 \%$ difference compared to the control). Comparison of the experimental groups revealed that the introduction of $\mathrm{SiO}_{2}$ FDP promoted an increase in the concentration of silicon, phosphorus, and calcium in the ruminal fluid. The introduction of FeCo FDP was accompanied by a decrease in the concentration of iron and cobalt in the ruminal fluid. Thus, the use of feed additive in finely dispersed form in the diet of animals was accompanied by an increase in the use of calcium and phosphorus by the animal's body, which is advisable when intensifying milk and meat productivity. The obtained results require further research.

Keywords: finely dispersed forms of microelements, ruminants, calcium and phosphorus exchange, feeding

\section{Introduction}

Currently, the problem of optimizing the mineral nutrition of farm animals is being solved using various mineral feed additives [1].

Studies of many authors indicate that highly dispersed forms in comparison with minS OPEN ACCESS 
productive effect [2-6]. It is possible to correct a number of physiological processes in the body by means of highly dispersed forms $[7,8]$.

From literary sources it is known that the inclusion of micronutrients of iron and cobalt in a highly dispersed form in the diet showed an increase in the content of calcium and phosphorus, since iron can promote the absorption of calcium, and calcium is closely associated with phosphorus in metabolism. It is known that calcium is necessary for normal formation of bone tissue of a growing organism and lactation of adult animals. In addition, calcium is an activator of the enzyme system and blood coagulation. Calcium is vital for the functioning of heart, muscles. It regulates the permeability of cell membranes, affects the availability of phosphorus, zinc and other elements. According to A.V. Skalny, phosphorus is located in biological media in the form of a phosphate ion, which is a part of inorganic components and organic biomolecules [9]. In animals, it is closely associated with calcium and vitamin D. Phosphorus is a part of bone tissue, and is found in phosphoroproteins, nucleic acids and phospholipids, it plays an important role in carbohydrate metabolism in the formation of ATP. Also, phosphorus is an essential component of cellular proteins.

It is known that feed is the main source of minerals for the body, but quite often it is not enough for an adequate nutrition of animals. In this regard, an urgent task is to replenish the deficiency of minerals in the diets of cattle.

Thus, this study is aimed at evaluating the use of mineral substances in the form of FDP in feeding young cattle.

\section{Material and research methods}

The studies were carried out in the Common Use Center of the Federal Research Center for Biological Systems and Agricultural Technologies of the Russian Academy of Sciences and Pokrovsky Agricultural College, a branch of Orenburg State Agrarian University.

To conduct a physiological experiment using pair analogue method, 3 groups ( $n=$ 5) of the Red Steppe bulls at the age of 13 months were formed. Animals of group I received $\mathrm{SiO}_{2} \mathrm{FDP}$ at a dose of $13 \mathrm{mg} / \mathrm{kg}$, group II - finely dispersed $\mathrm{FeCo}$ alloy at a dose of $5 \mathrm{mg} / \mathrm{kg}$ live weight. Animals of the control group were not fed with FDP. To obtain ruminal contents, rumen fistulas were placed. Samples of cicatricial contents $(300 \mathrm{ml})$ were obtained 6 hours after administration of FDP. During the preparatory period (10 days), the bulls were moved to tie-up housing, individual feeding. The experimental bulls were fed in groups. 
Animal care and experimental studies were performed in accordance with instructions and recommendations of Russian Regulations, 1987 (Order No. 755 on 08/12/1977 the USSR Ministry of Health) and "The Guide for Care and Use of Laboratory Animals (National Academy Press Washington, DC 1996) ". In the experiment, we made efforts to minimize animal suffering and to reduce the number of samples used.

Elemental composition of ruminal fluid of animals was studied in the laboratory of ANO Center for Biotic Medicine, Moscow (accreditation certificate No. ROSS RU.0001.22PYa05) by atomic emission spectrometry and mass spectrometry with inductively coupled plasma (Optima 2000 V, "Perkin Elmer" USA) and mass-spectral research method (Elan 9000, Perkin Elmer, USA).

During the accounting period when food intake and its residues were recorded, average samples of feces $(10 \%)$ and urine $3 \%$ of the total amount per day were collected, studies were carried out using the methods of zootechnical analysis. The content of calcium and phosphorus in feces and urine samples was determined by volumetric and colorimetric methods. These analyzes were carried out at the Testing Center of the Federal Research Center for Biological Systems and Agricultural Technologies of the Russian Academy of Sciences.

The obtained experimental data were subjected to conventional biometric processing using MS Excel 2007 software package. The reliability was assessed using Student's t-test

\section{Research results}

Elemental composition of ruminal fluid. The inclusion of finely dispersed microelements in the diet had an effect on the amount of essential and conditionally essential chemical elements (Table 1). It was shown that animals from the experimental groups that were fed with diets containing silicon dioxide and cobalt iron alloy, an increase in the content of the following elements was observed: calcium by $32 \%$ and by $11 \%$; phosphorus by $12 \%$ and $61 \%$, silicon by $4 \%$ and $17.4 \%$.

Table 1.

At the same time, a significant decrease in the cobalt content by $50 \%(P \leq 0.05)$ was noted in ruminal fluid of the animals from group II. In contrast to group II, I group had no significant differences in the concentration of essential trace elements after six hours of digestion. 
TABLE 1: The difference in the concentration of chemical elements in ruminal fluid of animals of the experimental groups in comparison with control: $\mathrm{A}-\mathrm{SiO}_{2}$ FDP (group I); B - FeCo FDP (group II), \%.

\begin{tabular}{llll} 
Element & \multicolumn{3}{c}{ Group } \\
& I & II & Control \\
Co & $0,07 \pm 0,01$ & $0,03 \pm 0,005^{*}$ & $0,06 \pm 0,008$ \\
$\mathrm{Fe}$ & $105 \pm 10$ & $98,7 \pm 4,74$ & $99,5 \pm 9,95$ \\
$\mathrm{Ca}$ & $683 \pm 68$ & $575 \pm 58$ & $518 \pm 52$ \\
$\mathrm{P}$ & $410 \pm 41$ & $592 \pm 59$ & $367 \pm 37$ \\
$\mathrm{Si}$ & $19,1 \pm 1,91$ & $21,6 \pm 2,17$ & $18,4 \pm 1,84$ \\
& \multicolumn{3}{r}{ Note: $^{*}-\mathrm{P} \leq 0.05$} \\
\end{tabular}

TABLE 2: Average daily calcium balance in experimental animals, g/head.

\begin{tabular}{|c|c|c|c|}
\hline \multirow[t]{2}{*}{ Index } & \multicolumn{3}{|c|}{ Group } \\
\hline & I & II & Control \\
\hline Introduced & $71,20 \pm 0,115^{* * *}$ & $70,37 \pm 0,186^{* *}$ & $69,43 \pm 0,260$ \\
\hline Excreted in feces & $37,91 \pm 1,616$ & $37,49 \pm 1,641$ & $41,82 \pm 1,057$ \\
\hline Excreted in urine & $6,10 \pm 0,3005$ & $5,80 \pm 0,5689$ & $6,78 \pm 0,0033$ \\
\hline Deposited per 1 head & $27,2 \pm 1,324^{*}$ & $27,07 \pm 1,944^{* *}$ & $20,8 \pm 0,928$ \\
\hline $\begin{array}{l}\text { Deposited per } 100 \mathrm{~kg} \text { of live } \\
\text { weight }\end{array}$ & $8,16 \pm 0,382^{*}$ & $8,13 \pm 0,574^{* *}$ & $6,26 \pm 0,275$ \\
\hline Utilization rate, $\%$ & $38,19 \pm 1,854^{*}$ & $38,46 \pm 2,690^{* *}$ & $30,00 \pm 1,389$ \\
\hline \multicolumn{4}{|c|}{ Note: ${ }^{*}-\mathrm{P} \leq 0.05 ;{ }^{* *}-\mathrm{P} \leq 0.01 ;{ }^{* * *}-\mathrm{P} \leq 0.001$} \\
\hline
\end{tabular}

Exchange of calcium and phosphorus. As a result of research, it was revealed that the use of finely dispersed microelements in animal feeding was accompanied by some changes in the use of calcium (Table 2).

The best use of calcium, both in absolute and in relative terms, compared with the control group, was registered in young animals of all experimental groups. In the body of experimental animals, more calcium is deposited: in group I - by $30.8 \%(P \geq 0.05)$, in group II - 30.3\% ( $\mathrm{P} \geq 0.01)$. In comparison with the control, the utilization rate was higher in group I by $27.3 \%(P \geq 0.05)$, in group II $-28.2 \%(P \geq 0.01)$.

Thus, the animals were provided with calcium, while bulls from the experimental groups used it better.

In preent studies, the exchange of phosphorus in the body of experimental animals was studied (table 3).

The use of highly dispersed forms of microelements made it possible to increase significantly the amount and degree of phosphorus absorption in feed. Thus, in group I weight of phosphorus assimilated by bull calves exceeded that in the control group by $5.11 \mathrm{~g}(40 \%)(P \leq 0.01)$. 
TABLE 3: Average daily phosphorus balance in experimental animals, g/head.

\begin{tabular}{|c|c|c|c|}
\hline \multirow[t]{2}{*}{ Index } & \multicolumn{3}{|c|}{ Group } \\
\hline & I & $\|$ & Control \\
\hline Introduced & $41,87 \pm 0,017^{* * *}$ & $41,85 \pm 0,087^{* * *}$ & $40,40 \pm 0,208$ \\
\hline Excreted in feces & $18,13 \pm 0,928$ & $22,78 \pm 0,318$ & $22,87 \pm 1,488$ \\
\hline Excreted in urine & $3,57 \pm 0,2833^{*}$ & $3,14 \pm 0,4997$ & $2,47 \pm 0,3333$ \\
\hline Deposited per 1 head & $20,17 \pm 0,668^{* *}$ & $15,94 \pm 0,668$ & $15,06 \pm 0,992$ \\
\hline $\begin{array}{l}\text { Deposited per } 100 \mathrm{~kg} \text { of live } \\
\text { weight }\end{array}$ & $6,14 \pm 0,171^{* *}$ & $4,78 \pm 0,200$ & $4,52 \pm 0,285$ \\
\hline Utilization rate, \% & $48,17 \pm 1,582^{* *}$ & $38,08 \pm 1,557$ & $37,30 \pm 2,613$ \\
\hline \multicolumn{4}{|c|}{ Note: * $-P \leq 0.05 ;{ }^{* *}-P \leq 0.01 ;{ }^{* *}-P \leq 0.001$} \\
\hline
\end{tabular}

During the experiment, the amount of phosphorus consumed with feed in the experimental groups was 3.6\% higher $(\mathrm{P} \leq 0.01)$ than in the control group. In terms of the amount of phosphorus excreted with feces, insignificant differences are observed between control and experimental groups. More phosphorus by $44.5 \%(P \leq 0.05)$ was excreted with urine in group I relative to control. So, the phosphorus content in the urine of bulls of I and II experimental groups averaged $3.57 \mathrm{~g}$ and $3.14 \mathrm{~g}$, while in the control - 2.47, it is $44.5 \%(P \leq 0.05)$ and $27.1 \%$ less. The use of phosphorus for deposition was higher in group I by $34 \%(\mathrm{P} \leq 0.01)$ and by $6 \%$ in group II in relation to the control.

The efficiency of phosphorus absorption depends on a number of factors: age, body weight of animal, physiological state, amount of consumed dry matter of the diet, calcium-phosphorus ratio, concentration of trace elements in feed, fat, $\mathrm{pH}$ in the intestine; source of phosphorus. Animals of the experimental groups, in comparison with their peers in the control group, deposited more calcium and phosphorus in the body. Moreover, they had higher utilization rates of these elements.

It should also be noted that bulls fed with finely dispersed forms of microelements in their diet had higher rates of phosphorus utilization from its amount received with feed. The experimental animals of group I exceeded their peers from the control by $29 \%$ in this indicator. In the bulls of group II, the phosphorus utilization rate was lower.

Thus, the mineral metabolism in the rumen of young cattle can be adjusted through the additional introduction of finely dispersed microelements in the diet, in particular an alloy of iron and cobalt and silicon dioxide.

\section{Discussion}

The interest in the use of finely dispersed microelements in feeding polygastric animals is currently growing. The study of the balance of the main mineral elements is important 
in the regulation of metabolism in the body of polygastric animals, which makes it possible, based on the results obtained, to increase the productivity of animals.

It should be noted that the experiment showed a decrease in the concentration of iron and cobalt in ruminal fluid against the background of the introduction of FDP of FeCo alloy. Probably the reason for this is the triggering of homeostasis mechanisms, which leads to a decrease in the negative effects of excess iron in the body [10]. A similar result of a decrease in the iron content was observed in the muscles of rats upon intake of iron nanoparticles and their agglomerates [11].

Comparison of the experimental groups with each other revealed that the introduction of $\mathrm{SiO}_{2} \mathrm{FDP}$ promotes an increase in the concentration of silicon, phosphorus, and calcium in the ruminal fluid. Whereas the introduction of FeCo FDP was accompanied by a decrease in the concentration of iron and cobalt in the rumen fluid. This is probably due to the selective ability of bacteria to absorb trace elements and use them for their own needs [5]. The balance of calcium and phosphorus in the experimental animals was positive, which is associated with both the absence of factors aimed at increasing the elimination of trace elements from the body, and with their better assimilation. Similar results were previously obtained in studies on raising animals [12, 13].

\section{Conclusion}

Thus, the use of a feed additive in the form of finely dispersed microelements in the ration of animals is accompanied with an increase in the use of calcium and phosphorus by the animal's body, which is advisable for intensifying milk and meat productivity. The results obtained require further research.

\section{Acknowledgments}

The research was carried out with the financial support of the Russian Science Foundation project No. 20-16-00078.

\section{References}

[1] Neubert J, Wagner S, Kiwit J, Bräuer AU, Glumm J. New findings about iron oxide nanoparticles and their different effects on murine primary brain cells. International Journal of Nanomedicine. 2015;10:2033- 2049. 
[2] Roco MM. The long view of nanotechnology development: The National Nanotechnology Initiative at 10 years. Journal of Nanoparticle Research. 2011;13:427447.

[3] Elena Y, Sergey M, Elena S. Intestinal microbiome of broiler chickens after use of nanoparticles and metal salts. Environmental Science and Pollution Research. 2018,25(18):18109-18120.

[4] Makaeva AM, Atlanderova KN, Sizova EA, Nechitaylo KS. Elemental composition and ruminal digestion with nanosized forms of $\mathrm{SiO}_{2}$, $\mathrm{FeCo}$. В сборнике: IOP Conference Series: Earth and Environmental Science. The proceedings of the conference AgroCON-2019; 2019, 18-19 April, Kurgan, Russia.

[5] Makaeva AM, Aleshina ES, Sizova EA, Atlanderova KN. Cattle microbiocoenosis of rumen while various feed ultrafine particles release. В сборнике: IOP Conference Series: Earth and Environmental Science. The proceedings of the conference AgroCON-2019. 2019. 18-19 April, Kurgan, Russia.

[6] Makaeva A, Atlanderova K, Miroshnikov S, Sizova E. Rumen microbiome of cattle after introduction of ultrafine particles in feed. Federation of European Biochemical Societies Journal Open Bio. 2019;9(1):416-416.

[7] Vladimir F, Sergey m, Elena S, Alexander U, Elena M. Metal particles as traceelement sources: Current state and future prospects. Worlds Poultry Science Journal. 2018;74(3):523-540.

[8] Sekhon BS. Nanotechnology in agri-food production: An overview. Nanotechnology, Science and Applications. 2014;7:31-53.

[9] Skalny AV. Chemical elements in human physiology and ecology. Moscow: ONIX 21st century; 2004

[10] Aslam MF, Frazer DM, Faria $\mathrm{N}$ et al. Ferroportin mediates the intestinal absorption of iron from a nanoparticulate ferritin core mimetic in mice. Federation of American Societies for Experimental Biology Journal. 2014;28(8):3671-3678.

[11] Sizova E, Miroshnikov S, Yausheva E, Polyakova V. Assessment of morphological and functional changes in organs of rats after intramuscular introduction of iron nanoparticles and their agglomerates. BioMed Research International. 2015;2015:243173. 1-12

[12] Miroshnikov SA, Zavyalov OA, Frolov AN et al. The reference intervals of hair trace element content in hereford cows and heifers (Bos taurus). Biological Trace Element Research. 2017;180(1):56-62.

[13] Miroshnikov S, Kharlamov A, Zavyalov O et al. Method of sampling beef cattle hair for assessment of elemental profile. Pakistan Journal of Nutrition. 2015;14(9):632-636. 